\title{
What sort of turning point?
}

Vera Rich reports on the fate of dissident Soviet scientists in light of the recent release of Vladimir Bukovskii.

THE release of Vladimir Bukovskii, in "exchange" for the Chilean Communist leader Luis Corvalan, brings to the West one of the most significant figures in the human rights movement in the Soviet Union. It does not, however, appear to indicate any general amelioration of the plight of dissidents; indeed, following Bukovskii's release, a number of other dissidents and refusniks, including several prominent scientists, were arrested.

Bukovskii, who was first arrested in 1963 while still a student of biology, has spent ten of the last thirteen years in penal psychiatric hospitals, prisons, and strict regime labour camps. During one of his brief periods of freedom he managed to inform the outside world of the growing Soviet practice of employing psychiatric methods to repress political dissidents, thereby posing an ethical problem to Western psychiatrists as to what should be their professional relationship (if any) with those of their Soviet colleagues known to be involved in this abuse. Imprisoned once again, in 1974 Bukovskii was sent to the strict regime labour camp at Perm', where with his fellow prisoner, the psychiatrist Semeon Gluzman, he wrote the now-famous Manual of Psychiatry for Dissidents, which sets out self-defence strategies for those whose political or ethical convictions are judged by the authorities to be evidence of insanity.

Immediately on his arrival in Zurich, Bukovskii thanked those who had campaigned for his release and announced his intention of devoting the rest of his life, if necessary, to campaigning for his fellow prisonersof-conscience. In the euphoria of release, he said that he felt his liberation marked an important new trend in Soviet policy and was "a great victory for everyone". This hope, however, does not appear to have been justified. The "exchange" procedure which brought Bukovskii freedom has been tacitly denied by the Soviet authorities; officially, Corvalan was released due to the efforts of "progressive forces" throughout the world, while Bukovskii was expelled from the Soviet Union as a terrorist. And, a few days after Bukovskii's release, another former long-term psychiatric detainee, the electrical engineer Vladimir
Borisov, was rearrested.

Borisov, who was released in 1974, had spent the major part of the previous eleven years in penal psychiatric hospitals for having organised an unauthorised youth group. During his captivity, he took part with Viktor Fainberg in a hunger-strike to protest against the conditions under which the prisoners are kept and the denial of their basic rights. Borisov's rearrest, on December 25, was allegedly in connection with the anti-Soviet slogans which appeared on walls in Leningrad earlier this year; dissident sources in Leningrad, however, interpret it as a warning from the authorities not to assume that Bukovskii's release marks a new 'thaw'. Borisov is at present, confined in a Leningrad psychiatric hospital in a block for 'acute' and violent cases, and has not yet been seen by the 'commission' of three psychiatrists which, legally, must decide on his case. His wife Irina is demanding that the commission should consist of psychiatrists whom she can trust, and has asked for Semeon Gluzman, Marina Voikhanskaya, and Gary Low-Beer.

This request is unlikely to meet with official approval. Dr Gluzman is still in the Perm' labour camp, where he was sent for exposing the 'official' diagnosis of insanity in the case of General Grigorenko. Dr Voikhanskaya, who formerly worked in the hospital where Borisov is now confined, was obliged to emigrate (leaving her young son behind) after her repeated refusals to administer psychotropic drugs to dissidents. Dr Low-Beer, of Horton Hospital, Epsom, a prominent campaigner against the political misuse of psychiatry, told Nature that he is quite willing to comply with Mrs Borisova's wish that he should examine her husband, and that although it is virtually impossible that the Soviet authorities would allow such a commission to decide Borisov's fate, he himself would press for and demand the right of access to the 'patient'.

Unlike Borisov's arrest, the arrest and harassment of some 45 Jewish refusniks in Moscow (including the physicists Mark Azbel and Aleksandr Lerner, the mathematician Viktor Brailovskii, and Academician Veniamin Levich, an electrochemist) is not directly associated with the release of Bukovskii. The group, members of the now-famous Sunday seminars for dismissed scientists, had been under pressure for some weeks following the announcement of their intention to hold a symposium on Jewish fife and

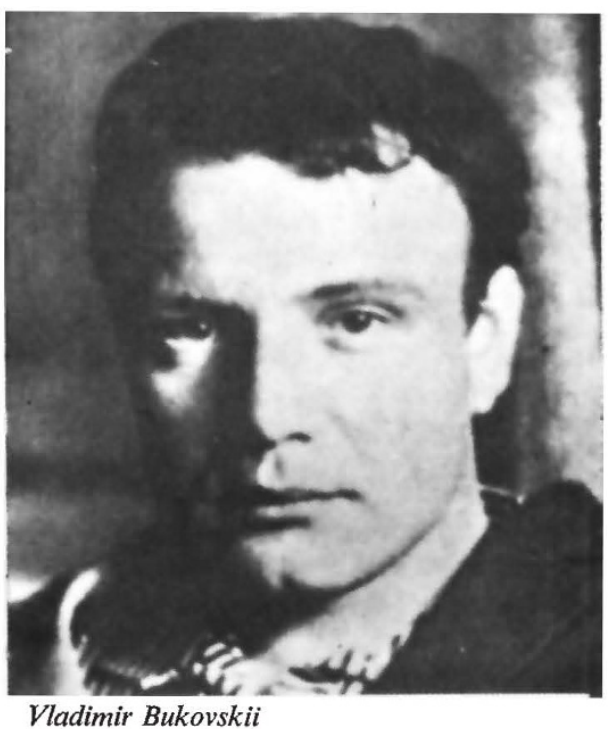

culture in the Soviet Union. (A growth of Jewish consciousness is, not unsurprisingly, a common phenomenon among the refusniks).

The group had been warned that if they persisted in going ahead with their plans, the authorities would take action. The threat was reinforced by a vicious attack in Izvestiya on Aleksandr Voronel, the founder of the group, who emigrated to Israel in December 1974; this called him a "former scientist without a future, indeed without a present", a "trader in human souls" and an "unmasked provocateur". The article recalled how, in summer 1974, Voronel's efforts to hold an international session of the seminar "failed completely"-as indeed it did, since would-be participants from abroad were refused visas and the "hosts" were arrested or subjected to severe harassment. A repetition of these tactics in the case of the Jewish symposium was therefore expected; it was hoped, however, that the authorities would intervene simply to break up the symposium, and that there would be no long-term arrests.

This, unfortunately, has not proved to be the case. Criminal proceedings have commenced against one of the would-be participants, the physicist Naum Salanskii from Vilnyus, on the grounds that the paper he had prepared for the symposium slandered the Soviet Union by giving incorrect information about the treatment of the Jewish minority. In Leningrad, a Jewish mechanical engineer, Vladimir Shverdlin, was arrested on a charge of unlawful possession of weapons (apparently a few bullets left over from his membership, some years back, of a shooting club); although he has since been released, his family have been informed that the results of the investigation have been "passed on to the Procurator". 
In spite of such warnings, the human rights campaign still continues. Following the arrest of Borisov, a group of eighteen Moscow dissidents has called for a renewed campaign against the political abuse of psychiatry. In Kiev, a 'Helsinki monitoring group' has been set up, similar to that set up earlier this year in Moscow; its members include Nina Strokata-Karavans'ka, a microbiologist, and the science-fiction writer Mykola Rudenko.

\section{USA}

- President Ford's final budget, which is expected to be delivered to Congress on January 17 (just three days hefore his successor is inaugurated), will promise large increases in funds for research and development and propose that the green light be given to several important and eagerly-awaited scientific projects. Though it's possible that the whole budget document could be turfed out by the incoming Carter Administration, Mr Carter will have more pressing matters on his mind than tinkering with the nuts and bolts of the federal government's science programmes; it is therefore likely that some of $\mathrm{Mr}$ Ford's lame-duck proposals will survive more or less intact.

The rough outline of the proposed budget for research and development was sketched out last month by Guy Stever, the President's science adviser, who is also about to leave the government. Stever called a press conference after meeting to discuss the budget with $\mathrm{Mr}$ Ford, a number of prominent people from the scientific community and government officials from science agencies. $\mathrm{He}$ announced that Ford will propose that basic research be given a real increase, amounting to about $3 \%$ above the rate of inflation, in the fiscal year which begins on October 1, 1977, and that some of the increase would be spent on new projects in agricultural research, space science and earthquake prediction.

Following the pattern established in his two previous budgets, President Ford will propose particularly large increases in military science and technology and energy research and development. The proposed increase in military science alone will amount to about $15 \%$, Stever said. Carter will take a close look at both those two areas, however, and Ford's proposals should therefore be taken with more than a pinch of salt.

As for space science, the proposed budget will contain some good news for astronomers and planetary scientists. Last year, in an effort to reduce public expenditure, the Ford Administration stripped about $\$ 200$ million from the budget of the National Aeronautics and Space Administration shortly before it was sent to Congress, and NASA was consequently forced to defer plans to build the Large Space Telescope (LST) and to start work on a spacecraft to orbit Jupiter.
Those funds will he reinstated in this year's budget, however, and if approved by the Congress and by the Carter Administration, the LST should be ready for launch in the early 1980s and the Jupiter mission will be launched in 1981. Both missions rank high on the list of priorities for space research drawn up by the National Academy of Sciences.

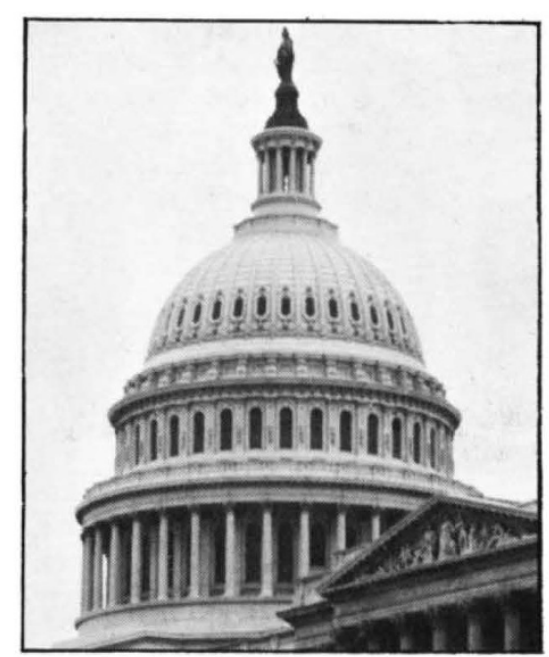

Another space project which Ford will approve is construction of a fourth satellite in the Earth Resources Technology Satellite series, called Landsat-D. The Landsat programme has consistently received strong support from Congress, and Ford's proposals will probably be accepted.

The lame-duck budget will also include a large helping of money for earthquake research, another area in which Congress has taken an interest. President Ford will propose that funds for earthquake monitoring and prediction be doubled in the next fiscal year, to reach about $\$ 50$ million. The money would be divided between the US Geological Survey, which operates a number of seismic stations and research establishments in California, and the National Science Foundation. No details are available of the projects which will benefit from this largesse, however.

Finally, in agricultural research, President Ford has decided to implement a proposal which has been advanced by three committees of the National Academy of Sciences and by two committees of the House of Representatives. He will propose the initiation of a new programme of competitive grants, funded through the Department of Agriculture, for basic research related to agriculture. The new programme, which would receive about $\$ 35$ million next ycar under Ford's proposal, will complement rather than replace the Agriculture Department's traditional block grant system for agricultural research.

Usually, budget details are not released until the proposals are sent to Congress, but in this case, the tradition was broken presumably because the figures for research and development look good. Since Guy Stever and the Office of Science and rechnology Policy can claim a good deal of the credit, they were understandably keen to get the word out before Stever departs.

- The National Academy of Sciences has finally added its voice to the chorus of criticism directed at the socalled 'hot particle' theory. Put forward in 1974 by Drs Thomas Cochran and Arthur Tamplin, staff scientists at the Natural Resources Defense Council, the theory is that tiny particles of inhaled plutonium may lodge in the lung and deliver a prolonged, intense dose of radioactivity to a small area of surrounding tissue, thereby posing a severe cancer hazard. NRDC argued that since present plutonium exposure standards are based on average doses of radioactivity to the entire lung, they underestimate the health hazards and should be tightened by a factor of about 115,000. Such strict standards would present a problem for reprocessing and plutonium fabrication plants.

In a report published last month, however, an Academy committee concludes that the evidence doesn't support the hot particle theory and that there is no need to lower plutonium exposure standards. The committee, which examined the theory under contract to the Environmental Protection Agency, looked at the results of tests on beagle dogs and concluded that the observed incidence of cancer doesn't fit in with the hot particle theory, and suggested that it "can adequately be accounted for by averaging the absorbed alpha radiation dose over the whole lung." The committee also argues that epidemiological cvidence from experience with inhaled alpha-emitting particles suggests that the usual method of applying an average radiation dose to the whole lung to predict carcinogenic effects.

Colin Norman 